\title{
A PRE-PLANNING FOR HOTEL LOCATING ACCORDING TO THE SUSTAINABILITY PERSPECTIVE BASED ON BWM-WASPAS APPROACH
}

\author{
Sarfaraz HASHEMKHANI ZOLFANI ${ }^{1,}$, Sepideh MOSHARAFIANDEHKORDI ${ }^{2,3}$, \\ Vladislavas KUTUT ${ }^{4}$ \\ ${ }^{1}$ Catholic University of the North, School of Engineering, Larrondo 1281, Coquimbo, Chile \\ ${ }^{2}$ Office of Sustainability, Amirkabir University of Technology (Tehran Polytechnic), Tehran, Iran \\ ${ }^{3}$ Department of Civil and Environmental Engineering, Amirkabir University of Technology (Tehran Polytechnic), \\ P.O. Box 15875 -4413, Hafez Ave, Tehran, Iran \\ ${ }^{4}$ Department of Construction Management and Real Estate, Vilnius Gediminas Technical University, \\ Sauletekio al. 11, LT-10223 Vilnius, Lithuania
}

Received 30 October 2018; accepted 23 June 2019

\begin{abstract}
Finding an appropriate location from any kind of perspectives is a really vital issue for businesses. Searching for the best location to meet a business perspective which can be also a sustainable one would be really challenging and it needs pre-planning. Locating for business issues in tourism industry for instance hotel locating is one of the major complicated topics in this area. Locating can come along with pre-planning and kind of feasibility studies which can cover all necessities of current and future needs of an issue. Locating with sustainability point of view is one the newest approach in different studies which this research is also working on that based on a hybrid Multiple Attribute Decision Making (MADM) model. MADM methods are really suitable ways in making complicated decisions in different areas. A hybrid MADM model based on BWM-WASPAS is applied for locating problem in finding the best location for the hotel locating challenge. To meet the aim of this research, a case study for evaluating probable locations of a five star hotel examined for the Shahrekord city, Iran. As locations were prioritized based on sustainability perspective, business goals can also be seen as a pre-planning project.
\end{abstract}

Keywords: Multiple Attribute Decision Making (MADM), hotel locating, pre-planning, sustainability perspective, Best Worst Method (BWM), Weighted Aggregated Sum Product Assessment (WASPAS).

\section{Introduction}

Hotels play a prominent role in the success of tourism industry and development of a new hotel project with high quality facilities is a critical and costly issue which needs thoughtful strategic planning and management (Godinho, Phillips, \& Moutinho, 2018). Before construction and operation of the specific project, multifarious factors should be carefully considered and analyzed. In this regard, one of the most significant factors to be considered is the choosing the potential locations related to the purpose of the project (Adam \& Amuquandoh, 2013). According to a successful hotel manager, the three critical elements of a successful hotel are location, location, and location (Medlik, 1993). Therefore, assessment of potential locations is the first step toward the development of a successful hotel (K. W. Lee, H. B. Kim, H. S. Kim, \& D. S. Lee, 2010).
As it mentioned, the hotel sector is highly influenced by the location and the issue of location is one of the most fundamental elements due to various reasons (Adam \& Amuquandoh, 2013; Hanai, Oguchi, Ando, \& Yamaguchi, 2008; Lowe \& Kruger, 1991; Oppermann \& Brewer, 1996). One of the main reasons mentioned in different researches is the profound effect of location on the hotel selection by tourists and the satisfaction of the clients. The location of the hotel has the high priority among factors of choosing the suitable hotel by customers which also affect the choice of their destinations (Chu \& Choi, 2000; Ekinci, Prokopaki, \& Cobanoglu, 2003; Chan \& Wong, 2006; Hsieh, L. H. Lin, \& Y. Y. Lin, 2008; Lee et al., 2010). Besides, according to Lado-Sestayo, Vivel-Búa, and OteroGonzález (2016) the tourist firm performance and survival highly rely on the location. In addition, as a result of the research conducted by Shoval, McKercher, $\mathrm{Ng}$, and

*Corresponding author. E-mail: sa.hashemkhani@gmail.com 
Birenboim (2011), the impact of the hotel's site on tourists' movement and behavior is another essential reason of the importance of the hotel location in the hotel sector. Profitability, risk reduction, and competitive advantage are other reasons which highlighted by Luo and Yang (2016).

Additionally, because of the importance of the locating in the stages of the hotel development, all dimensions, elements, and considerations regarding hotel location selection in both the short-term and the long-term should be evaluated through a comprehensive and systemic model (Adam \& Amuquandoh, 2013). Investing in site selection for hotels is not only beneficial but also necessary due to its direct importance in hotel's success (Lee et al., 2010; Aksoy \& Yetkin Ozbuk, 2017). There are a large number of factors and elements which affect the location selection decisions which make this task extremely complex and sophisticated (Adam \& Amuquandoh, 2013; Lee et al., 2010). Since the rectification of the wrong location is not a rational and practical solution, identifying the patterns and models for evaluating locations is in high demand and considered as a valuable asset for investors (Yang, Luo, \& Law, 2014).

Moreover, nowadays, the issue of sustainability has become essential in all parts of the world due to its importance in all aspects of life. Limited natural resources, economic crisis as well as social issues led the world to step toward sustainable development. One of the industrial sectors which have recently received particular attention is hospitality, including the hotel sector. The current growing trend of tourists' knowledge of environmental conservation and sustainability issues in the world, is affecting a tourism industry including choices of tourism destination and change the approach of the tourism into considering sustainability in their selection factors (Hashemkhani Zolfani et al., 2018a; Azouz \& Galal, 2016). Consequently, in order to choose a proper site for locating a hotel along with considering sustainability, various aspects including economic, social, cultural and environmental aspects, which are important for successful hotel development should be analyzed systematically (Adam \& Amuquandoh, 2013; Luo \& Yang, 2016).

One of the most applicable methodologies for locating topics is MADM methods (Vafaeipour, Hashemkhani Zolfani, Morshed Varzandeh, Derakhti, \& Keshavarz Eshkalag, 2014). There are so many MADM methods which can apply for decision making about different things specially locating a special place. MADM methods can find suitable answer for evaluating probable alternatives as locations based on certain criteria. As it will be discussed more in literature review part, so many studied applied for finding the best location based on MADM methods. Choosing a proper method or combination of methods as a hybrid model is also a challenging topic in applying MADM methods about decision making about different topics and locating isn't something beyond that. So, this research is trying to select an appropriate model for the process of decision making. This research applies a new hybrid MADM method for the evaluation of alternatives as locations which can be a new framework for the complicating and challenging decisions in the future. BWMWASPAS as the hybrid model is applying and based on that the model will be solved. BWM will apply for pairwise comparison of criteria and WASPAS for ranking and evaluating alternatives. This locating study is based on a case from Shahrekord city of Iran and feasible study of finding a right place for locating a five star hotel is mentioned.

\section{Literature review about MADM methods and location problems}

As it mentioned in the introduction section, MADM methods have been applying for the problem of locating since so many years ago. As other research areas, for different aims and outputs there are many methods as the way doing research. So, there are other ways for locating but based on criteria and defined scope MADM methods are one of the best for decision making. As it can be seen, in some cases applied methods are different and hybrid models are really common in the literature. Some studies with the background of hotel locating have been already presented in the previous (introduction) section. Some related studies about locating based on MADM methods about different location problems have selected and presented in Table 1.

As it can be illustrated based on Table 1, references from high quality journal and proceedings were selected to be listed in the literature review overview. Also, authors tried to select those references which could cover different varieties of MADM methods. The literature covered more than 10 common MADM methods for locating problems which shows how much MADM methods are common for solving these kinds of problems. Eventually, as it can be seen the new hybrid model of this study is a unique way of locating based on MADM methods for solving real world problems.

Some other related studies with more concentrate on sustainability issues, MCDM methods and related topics such as: Building (Manupati, Ramkumar, \& Samanta, 2018): due to rapid urbanization in Indian cities, urban renewal process is too challenging so based on new plan of India's government they are trying to work on smart cities mission there. This policy making in the south of India has done based on DANP methodology. The vision of this study has a foresight perspective which is related to the locating challenge which is widespread everywhere; Smart cities and Urbans (Si \& Marjanovic-Halburd, 2018): constructed facilities (Elzarka, Yan, \& Chakraborty, 2017), institutional owners are increasingly working on effective ways for decreasing negative impacts on the environment. Working based on renewable energy generation can decrease utility bills and the most important one can be institution's public image. So, locating based on sustainability perspective and managing based on that can be an appropriate managing think in term of so many vital issues; classifying urban residential areas (Marques, 
Table 1. Previous and selected studies about locating problems and MADM methods

\begin{tabular}{|c|c|c|c|}
\hline & Topic & Main methods & References \\
\hline 1 & Locating a nuclear power plant & Fuzzy Entropy & (Erol, Sencer, Ozmen, \& Searly, 2014) \\
\hline 2 & Selection of the logistics center location & ELECTRE III/IV & (Zak \& Weglinski, 2014) \\
\hline 3 & City logistics concept selection & $\begin{array}{l}\text { Fuzzy DEMATEL, Fuzzy ANP, Fuzzy } \\
\text { VIKOR }\end{array}$ & (Tadic, Zecevic, \& Krstic, 2014) \\
\hline 4 & Liquefied natural gas terminal & SAW, TOPSIS, COPRAS & (Bagocius, Zavadskas, \& Turskis, 2014) \\
\hline 5 & Assessment of neglected areas & COPRAS & $\begin{array}{l}\text { (Bielinskas, Burinskienė, \& Palevičius, } \\
\text { 2015) }\end{array}$ \\
\hline 6 & Glasshouse locating & SWARA, COPRAS & $\begin{array}{l}\text { (Haghnazar Kouchaksaraei, Hashemkhani } \\
\text { Zolfani, \& Golabchi, 2015) }\end{array}$ \\
\hline 7 & Offshore wind farm site selection & $\begin{array}{l}\text { Fuzzy ANP, Fuzzy ELECTRE, Fuzzy } \\
\text { DEMATEL }\end{array}$ & (Fetanat \& Khorasaninejad, 2015) \\
\hline 8 & Facility location & $\begin{array}{l}\text { TOPSIS, SAW, ELECTRE-1, } \\
\text { MOORA, GRA }\end{array}$ & (Ray, De, \& Dan, 2015) \\
\hline 9 & Emergency service station location & PROMETHEE IV & $\begin{array}{l}\text { (Esmaelian, Tavana, Santos Arteaga, \& } \\
\text { Mohammadi, 2015) }\end{array}$ \\
\hline 10 & Dry port location & CFA, MACBETH, PROMETHEE & (Komchornrit, 2017) \\
\hline 11 & Garage location selection & WASPAS & (Bausys \& Juodagalviene, 2017) \\
\hline 12 & Location of wind farms & DEMATEL, ANP, MABAC & $\begin{array}{l}\text { (Gigović, Pamučar, Božanić, \& Ljubojević, } \\
\text { 2017) }\end{array}$ \\
\hline 13 & Solar farm location planning & Fuzzy AHP & $\begin{array}{l}\text { (Tavana, Santos Arteaga, Mohammadi, \& } \\
\text { Alimohammadi, 2017) }\end{array}$ \\
\hline 14 & A military airport location & AHP, PROMETHEE, VIKOR & (Sennaroglu \& Celebi, 2018) \\
\hline 15 & Selection of a car sharing station & WASPAS, TOPSIS & (Devici, Canitez, \& Gokasar, 2018) \\
\hline 16 & $\begin{array}{l}\text { Location selection for a solar PV power } \\
\text { plant }\end{array}$ & AHP & (Ozdemir \& Sahin, 2018) \\
\hline 17 & Bike-share stations & AHP, MOORA & $\begin{array}{l}\text { (Kabak, Erbas, Cetinkaya, \& Ozceylan, } \\
\text { 2018) }\end{array}$ \\
\hline 18 & Sustainable desalination plant location & AHP & (Dweiri, Ahmed Khan, \& Almulla, 2018) \\
\hline 19 & Strategic retail location & Hesitant AHP, GRA & (Yildiz \& Tuysuz, 2018) \\
\hline 20 & Hotel location & SWARA, WS PLP & $\begin{array}{l}\text { (Popovic, Stanujkic, Brzakovic, \& } \\
\text { Karabasevic, 2019) }\end{array}$ \\
\hline
\end{tabular}

Ferreira, Meidutè-Kavaliauskienè, \& Banaitis, 2018): the study mentions how urban residential areas should be designed based on their exposure to crime. So, just preparing services like being cheap won't solve all problems and challenges in reality. As it can be seen this research is shown that how much locations can be an important topic. The Architect and the Paradigms of Sustainable Development (Bonenberg \& Kaplinski, 2018): a basic concept which can be thinking about sustainable architecture from the zero point. So, it is more than just locating and the process of the construction can be sustainable. Key Factors of Sustainable Architecture (Amoozad Mahdiraji, Arzaghi, Stauskis, \& Zavadskas, 2018): the same as previous study sustainable architecture can be really important. Priority of construction ways and selected criteria can be different and the case study is about Iran which can be a signal to see that sustainability is going to be a procedure in the country so not only the architecture but also locating will be an important issue in between. Eventually, as it can be seen which show how much MADM methods are involve with important decision makings about related issues.

\section{Problem statement}

The same as some studies this study can be considered as a pre-planning of the projects which can be mentioned as a feasible study for targeting a special aim (Hashemkhani Zolfani, Aghdaie, Derakhti, Zavadskas, \& Morshed Varzandeh, 2013; Hashemkhani Zolfani, Yazdani, \& Zavadskas, 2018b). Decision making based on MADM methods can be about current situation, short-term planning (Hashemkhani Zolfani \& Safaei Ghadikolaei, 2012) and long-term planning/Futures Studies such as Prospective MADM approach (Hashemkhani Zolfani, Maknoon, \& Zavadskas, 2016; Hashemkhani Zolfani, Zavadskas, Khazaelpour, \& Cavallaro, 2018c). A business or project needs a well-designed plan for each section of market. Finding the best possible location for a special service-based business seems a necessary thing which needs a pre-evaluation and pre-planning to follow the main goals of the project. One of critical approach to this project in this study is sustainability. Sustainable development and sustainability became a serious trend and approach in tourism industry 
which is undeniable and each tourism project should consider sustainability in all sections and levels of the business (Hashemkhani Zolfani, Sedaghat, Maknoon, \& Zavadskas, 2015; Niñerola, Sánchez-Rebull, \& Hernández-Lara, 2019). Selecting a location which can be as much as possible suitable for a project which has also sustainability approach, is a complicated situation which can be solved with MADM approach and its methods. This study is presenting a new hybrid MADM model to solve this problem which a new approach in calculating and modelling the situation.

\section{Methodology}

This study is established based on a new hybrid MADM model. BWM-WASPAS is applied for evaluating criteria and alternatives as the core of methodology. This new hybrid model is able to evaluate alternatives with a newer perspective. For those cases which there is no need for policy making pairwise comparison approach will be useful in evaluating the criteria. Typically, is better to use SWARA and similar approaches for evaluating criteria based on policies. In comparison to the SWARA-WASPAS (Hashemkhani Zolfani et al., 2013) hybrid model and for this study is better to apply BWM instead of SWARA method because there is no need for policy making and the process of decision making is based on scientific parameters. WASPAS as an updated applicable method can evaluate alternatives due to needs and decision makers can simply use it for their decision making problems. The procedure is shown is Figure 1.

\subsection{Best Worst Method (BWM)}

Best Worst Method as a new MADM method released for solving MCDM problems based on pairwise com-

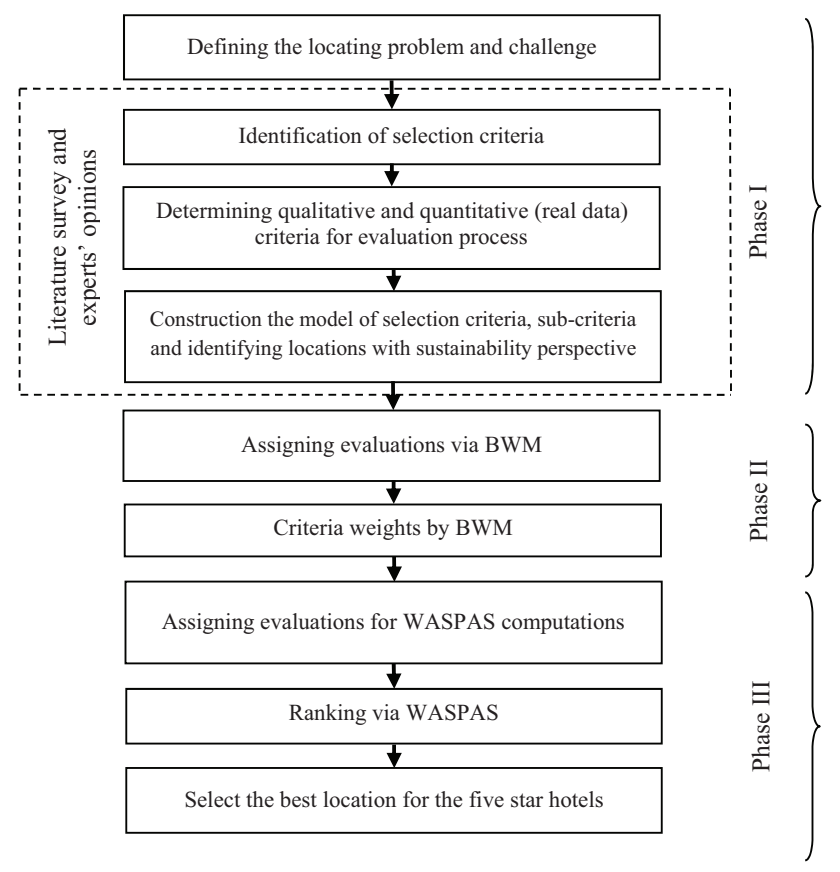

parison of criteria (Rezaei, 2015, 2016). MADM methods are working based on two stages and for different aims; first one is about weights of criteria and second one is about evaluating alternatives according to the criteria and their weights. Generally, BWM is applying for calculating relative importance (weights) of criteria. Normally, there are some similar methods to the BWM like: Analytic Hierarchy Process (AHP) (Saaty, 1980), Analytic Network Process (ANP) (Saaty, 1996), Step-wise Weight Assessment Ratio Analysis (SWARA) (Keršuliene, Zavadskas, \& Turskis, 2010), Factor Relationship (FARE) (Ginevičius, 2011), Simple Multi-Attribute Rating Technique (SMART) (Gupta \& Barua, 2016), Extended SWARA (Hashemkhani Zolfani et al., 2018b). In comparison to those methods (AHP, ANP, FARE and SMART), BWM is more consistent and has been using by scholars recently (Yadav, Mangla, Luthra, \& Jakhar, 2018). Due to the methodology of BWM, main point and core of structure is employing the most significant and least significant criteria which typically can be identified based on main decision makers ( $\mathrm{Sa}$ limi \& Rezaei, 2016). The general structure and steps of BWM method are presented below (Rezaei, 2015, Rezaei, Wang, \& Tavasszy, 2015):

1. Identifying selected criteria as a set of related ones to the topic. Set of criteria can be evaluated as $\mathrm{C}_{1}$, $\mathrm{C}_{2}, \mathrm{C}_{3}, \mathrm{C}_{4} \ldots \ldots \mathrm{C}_{\mathrm{n}}$.

2. Finding the best and worst criteria and as it mentioned above it should be done by experts and involved decision makers.

3. A matrix of preference of the best criterion over all others by applying numbers between 1 and 9. Generally, the results will represent the importance of the best criterion in comparison to the other criteria.

$$
A_{b}=\left(a_{1 B}, a_{2 B}, a_{3 B}, \ldots a_{n B}\right) .
$$

4. A matrix of preference of the worst criterion over all others by applying numbers between 1 and 9. Generally, the results will represent the situation of the worst criterion in comparison to the other criteria.

$$
A_{b}=\left(a_{1 W}, a_{2 W}, a_{3 W}, \ldots a_{n W}\right) \text {. }
$$

5. Relative importance of criteria through calculating the final and optimal weights for the criteria. The weights will show the same as: $w_{1}{ }^{*}, w_{2}{ }^{*}, w_{3}{ }^{*} \ldots . . w_{n}{ }^{*}$.

$$
\begin{aligned}
& \text { Minmax } \max _{j}\left\{\left|\left(w_{B} / w_{j}\right)-a_{B j}\right|,\left|\left(w_{j} / w_{w}\right)-a_{j w}\right|\right\} . \\
& \text { Subject to } \sum_{j} w_{j}=1, w_{j} \geq 0 \text {, for all values of } j .
\end{aligned}
$$

Eventually, checking consistency will be the last step. The same as AHP there is a consistency index which is shown in Table 2. Consistency ratio should be calculated as follow:

$$
\text { Consistency }=\frac{\xi}{\text { Consistency...index }} .
$$

Figure 1. The procedure of the research 
Table 2. Consistency Index table for BWM method

\begin{tabular}{|c|c|c|c|c|c|c|c|c|c|}
\hline $\mathrm{a}_{\mathrm{BW}}$ & 1 & 2 & 3 & 4 & 5 & 6 & 7 & 8 & 9 \\
\hline Consistency index $(\max \xi)$ & 0.00 & 0.44 & 1.00 & 1.63 & 2.30 & 3.00 & 3.73 & 4.47 & 5.23 \\
\hline
\end{tabular}

Some of recent research articles by BWM method as methodology are presented below:

- Chitsaz and Azarnivand (2016) for water scarcity management in arid regions.

- Rezaei, Hemmes, and Tavasszy (2017) for complex bundling configurations.

- Ren, Liang, and Chan (2017) in urban sewage sludge.

- Badri Ahmadi, Kusi-Sarpong, and Rezaei (2017) in assessing the social sustainability of supply chains.

- Rezaei, van Roekel, and Tavasszy (2018) for measuring logistics performance index indicators.

- Van de Kaa, Janssen, and Rezaei (2018) for identifying success factors for standard dominance.

- Nawaz et al. (2018) in cloud service selection.

- Salimi and Rezaei (2018) for evaluating firms' R\&D performance.

- Hashemkhani Zolfani and Chatterjee (2019) for comparative evaluation of sustainable design.

- Yadav, Mangla, Luthra, and Rai (2019) in developing a sustainable smart city framework.

- Pamucar, Chatterjee, and Zavadskas (2019) in assessment of third-party logistics provider.

- Omrani, Alizadeh, and Amini (2019) for calculating semi-human development index.

\subsection{Weighted Aggregated Sum Product Assessment (WASPAS)}

One of the newest MADM methods for evaluating the alternatives is WASPAS which has been developing since 2012 after introducing at the same year. This method is based on combination of Weighted Sum Model (WSM) and Weighted Product Model (WPM) (Zavadskas, Turskis, Antucheviciene, \& Zakarevicius, 2012).

WASPAS has simple steps which the first step of that is the same as other MADM methods for evaluating alternatives and that one is normalization. Normalization is based on (Stojic, Stevic, Antucheviciene, Pamucar, \& Vasiljevic, 2018):

$\bar{x}=\frac{x_{i j}}{\underset{i}{o p t} x_{i j}}$, where $i=\overline{1, m} ; j=\overline{1, n}$, if opt value is $\max ;(5)$

$\bar{x}_{i j}=\frac{\operatorname{opt}_{i j}}{x_{i j}}$, where $i=\overline{1, m} ; j=\overline{1, n}$, if opt value is min.(6)

For the next step two separated calculations are needed. One is WASPAS weighted and normalized decision making matrix for summarizing part and multiplication part:

$$
\bar{x}_{i j, \text { sum }}=\bar{x}_{i j} q_{j} \text {, where } i=\overline{1, m} ; j=\overline{1, n} \text {. }
$$

WASPAS weighted and normalized decision making matrix for multiplication part:

$$
\bar{x}_{i j, \text { mult }}=\bar{x}_{i j}^{q_{j}} \text {, where } i=\overline{1, m} ; j=\overline{1, n} \text {. }
$$

Finally, ranking and prioritizing alternatives based on half answers of two approaches which WASPAS shaped based on those.

$$
\begin{aligned}
& W_{P S}=0.5 \sum_{j=1}^{n} \overline{\bar{X}} i j, s u m+0.5 \prod_{j=1}^{n} \overline{\bar{X}} i j, \text { mult, } \\
& \text { where } i=\overline{1, m} ; j=\overline{1, n} .
\end{aligned}
$$

Some of recent studies by WASPAS method as the part of methodology are presented below:

- Karabašević, Stanujkić, Urošević, and Maksimović (2016) for personnel selection.

- Yazdani, Zavadskas, Ignatius, and Doval Abad (2016) in material selection.

- Zavadskas, Kalibatas, and Kalibatiene (2016) for choosing an optimal indoor environment.

- Khodadadi, Hashemkhani Zolfani, Yazdani, and Zavadskas (2017) in evaluating process of chemical wastewater purification.

- Mardani et al. (2017) as a systematic review and meta-analysis of SWARA and WASPAS methods.

- Devici et al. (2018) in selection of a car sharing station.

- Amjad Alam, Ahmed, Shafique Butt, Kim, and Ko (2018) for evaluating public cloud computing services.

- Balezentis and Streimikiene (2018) ranking of energy generation scenarios.

\section{Model of evaluation}

The main model of the research is about criteria. Those criteria which the evaluation will be based on them and locations will be evaluated based on them. Primary assessment of the locations was based on sustainability perspective to consider all prerequisites of environmental, economical and social aspects of building a five star hotel in a city with the specifications of a region like Shahrekord city. Based on the literature, the critical and important criteria for evaluating a location for building a hotel are selected and presented as Table 3.

For the evaluating criteria and weighting them, BWM will be applied and the results are presented in the section 6.

\section{Case study}

Shahrekord is the capital and the largest city of the Chaharmahal and Bakhtiari Province in Iran, surrounded by 
Table 3. The main criteria and sub-criteria for hotel locating

\begin{tabular}{|c|c|c|c|}
\hline Criteria & Sub-criteria & & References \\
\hline \multirow[t]{3}{*}{ Costs $\left(\mathrm{C}_{1}\right)$} & Cost of land in the location $\left(\mathrm{C}_{1-1}\right)$ & Min & \multirow{3}{*}{$\begin{array}{l}\text { (Hashemkhani Zolfani et al., 2013; Cheng, } \\
\text { Li, \& Yu, 2005; Hashemkhani Zolfani, } \\
\text { Pourhossein, Yazdani, \& Zavadskas, 2018a; } \\
\text { Chou, Hsu, \& Chen, 2008) }\end{array}$} \\
\hline & Cost of operation $\left(\mathrm{C}_{1-2}\right)$ & Min & \\
\hline & Site preparation cost $\left(\mathrm{C}_{1-3}\right)$ & Min & \\
\hline \multirow{6}{*}{$\begin{array}{l}\text { Facilities and } \\
\text { accessibility }\left(\mathrm{C}_{2}\right)\end{array}$} & Car parking facilities (Parking area) $\left(\mathrm{C}_{2-1}\right)$ & Max & \multirow{6}{*}{$\begin{array}{l}\text { (Adam \& Amuquandoh, 2013; Chou } \\
\text { et al., 2008; Yang, Wong, \& Wang, 2012; } \\
\text { Aksoy \& Yetkin Ozbuk, 2017; Azouz \& } \\
\text { Galal, 2016) }\end{array}$} \\
\hline & Proximity to public facilities and services $\left(\mathrm{C}_{2-2}\right)$ & $\operatorname{Max}$ & \\
\hline & Proximity to medical facilities $\left(\mathrm{C}_{2-3}\right)$ & Max & \\
\hline & Traffic convenience $\left(\mathrm{C}_{2-4}\right)$ & Max & \\
\hline & Proximity to the city center $\left(\mathrm{C}_{2-5}\right)$ & Max & \\
\hline & Open space $\left(\mathrm{C}_{2-6}\right)$ & Max & \\
\hline \multirow{3}{*}{$\begin{array}{l}\text { Access to } \\
\text { transportation }\left(\mathrm{C}_{3}\right)\end{array}$} & Closeness to the airport $\left(\mathrm{C}_{3-1}\right)$ & Max & \multirow{3}{*}{$\begin{array}{l}\text { (Adam \& Amuquandoh, 2013; Chou } \\
\text { et al., 2008; Yang et al., 2012; Aksoy \& } \\
\text { Yetkin Ozbuk, 2017; Azouz \& Galal, 2016; } \\
\text { Cheng et al., 2005) }\end{array}$} \\
\hline & Proximity to major roads $\left(\mathrm{C}_{3-2}\right)$ & Max & \\
\hline & Accessibility of public transport $\left(\mathrm{C}_{3-3}\right)$ & Max & \\
\hline \multirow{2}{*}{$\begin{array}{l}\text { Physical site } \\
\text { characteristics }\left(\mathrm{C}_{4}\right)\end{array}$} & View (Good scenery) $\left(\mathrm{C}_{4-1}\right)$ & Max & \multirow{2}{*}{$\begin{array}{l}\text { (Adam \& Amuquandoh, 2013; Azouz \& } \\
\text { Galal, 2016) }\end{array}$} \\
\hline & Outdoor noise $\left(\mathrm{C}_{4-2}\right)$ & Min & \\
\hline \multirow{2}{*}{$\begin{array}{l}\text { Potential continuous } \\
\text { development }\left(\mathrm{C}_{5}\right)\end{array}$} & Opportunity to expand the hotel in future $\left(\mathrm{C}_{5-1}\right)$ & $\operatorname{Max}$ & \multirow{2}{*}{$\begin{array}{l}\text { (Adam \& Amuquandoh, 2013; Cheng } \\
\text { et al., 2005) }\end{array}$} \\
\hline & $\begin{array}{l}\text { Closeness to other hotels already existed nearby } \\
\left(\mathrm{C}_{5-2}\right)\end{array}$ & Min & \\
\hline
\end{tabular}

mountains. It is located in the north of the Zagros Mountains and with a height of 2070 meters above sea level, is the highest capital of province in Iran which has been dubbed "the roof of Iran". The weather in Shahrekord is cold in winter and mild in summer.

Sharekord has plenty of historical and natural attractions as well as enchanting landscapes which is considered to be in the list of the main destinations of both national and international tourists in Iran. The city attracts the large number of tourists each year because of the historical places including Shahrekord Museum of Archeology, Mirror Room, Chaloshtor Castle, Dezak Castle, Atabakan Mosque, Zaman Khan Bridge, Sotudeh House, Chaloshtor Jame' Mosque, Imamzadeh Halimeh and Hakimeh Khatoon, etc. as well as the natural environment including rivers, springs, cascading waterfalls, wetlands, plains and ponds. Examples of natural attraction of Shahrekord are Zayandeh Rood River, Zardelime Waterfall, Choghakhor Lagoon, Cheshme Zaneh, Gerdab Ben, Solagan Wetland, and Tang-e-Sayad National Park. Meadows in Shahrekord are best places for horse riding and polo sports. Moreover, the city is popular because of its ski resort called Bardeh, which attracts many travelers to the city in winter.

Therefore, welfare facilities such as high quality hotels for tourists and travelers play a vital role in successful tourism industry in Shahrekord. However, currently, the demand for facilities and hotels especially, in the high season, is higher than the available capacity in the city, and the need for a comfortable hotel in Shahrekord is quite felt. Besides, one of the first and major factors in the stages of hotel development is the selection of a proper location for the hotel. In the following parts, the case study of locating a five-star hotel in Shahrekord will be elaborated.

\subsection{Preliminary study for locating a five star hotel in Shahrekord}

The case will be a Preliminary study for locating a fivestar hotel in Shahrekord contains luxury rooms and suites equipped with all amenities and communication facilities with a pleasant environment. The main amenities and facilities include conference hall, multi-cuisine restaurants and cafes, outdoor restaurant for summer, the leisure center, open spaces for social activities and interactions along with 24-hour room service.

\subsection{Candidate locations}

In the first step of choosing the location for hotel construction, there was tried to consider the main sustainability factors. Most of the selected sites have been chosen in the areas which have not considered as environmentally sensitive area in order to reduce environmental impacts. Another factor which considered in choosing the locations was the availability of roads and utilities to avoid the extra cost and energy. Most of the locations are in the places that enough land spaces are available for developing a high quality hotel. Other factors including, safety of area, environmental conditions and geographical factors, and current regulations have been considered. Finally, the five most suitable places have been selected in the first step. The descriptions of locations are explained in the following part.

- Locations have been finalized with the municipality of the city to check if there is a chance for getting official licenses and permissions. Some locations had to be deleted from the list because of local and national pandects. The exact locations and areas are illustrated in Figure 2 up to Figure 6. 
Location 1: East Ayatollah Kashani Boulevard

This location is situated in the East Ayatollah Kashani Boulevard which is one of the main boulevards in the city with easy access to the major roads.

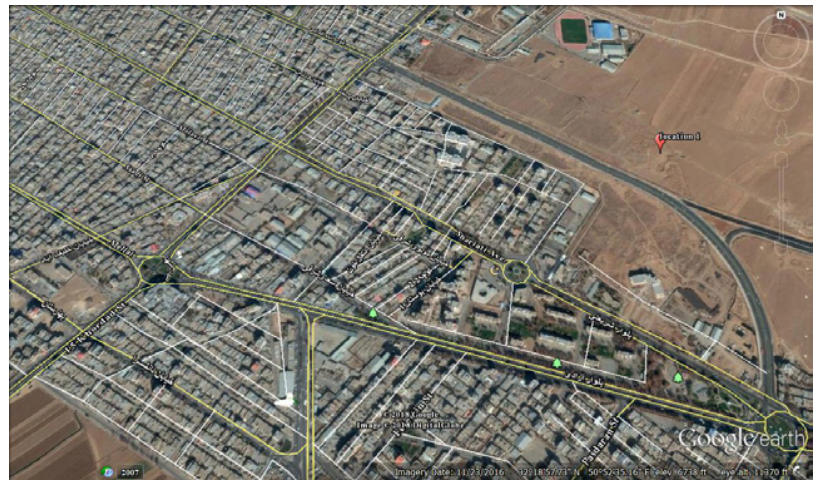

Figure 2. "East Ayatollah Kashani Boulevard" location

Location 2: Manzariyeh

This location is situated in Manzariyeh in the north of the city which is close to the Islamic Azad University, Shahrekord University of Medical Sciences and Parsian private hospital. It is a quiet place and located out of the residential part of the city.

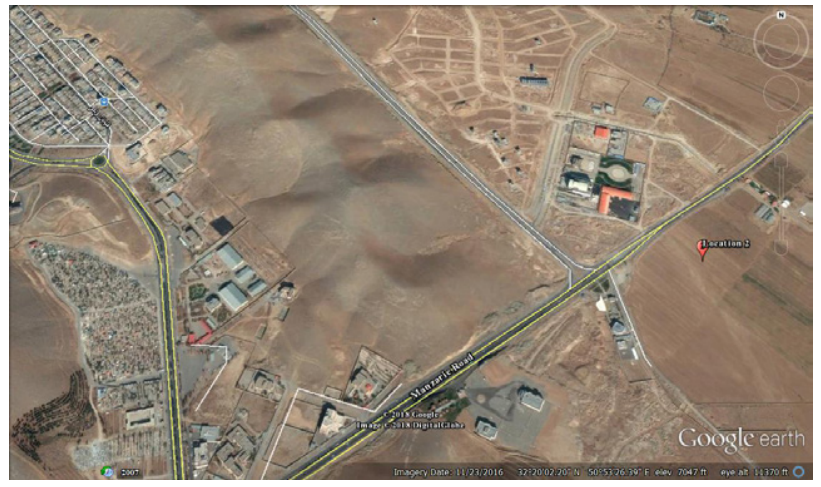

Figure 3. "Manzariyeh" location

Location 3: Khajeh Nasir-o-Din Toosi

This Site is situated in the south part of the city close to Khajeh Nasir-o-Din Toosi Boulevard and 15 Khordad Ring Road which is connected to the Shahrekord-Farsan Expressway. Another characteristic of this location is its closeness to the city center.

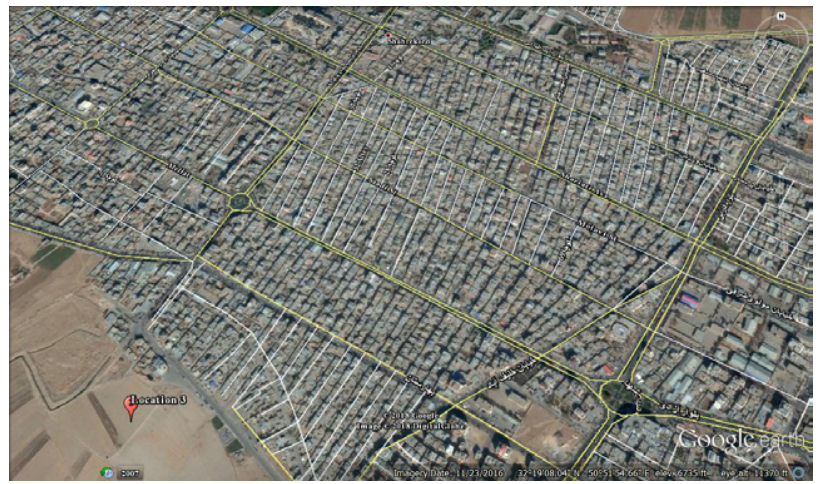

Figure 4. "Khajeh Nasir-o-Din Toosi" location
Location 4: Rahbar Boulevard

Location 4 is in the west of the city and located near 15 Khordad Ring road and Rahbar Boulevard with easy access to major roads. This location is close to the Shahrekord University.

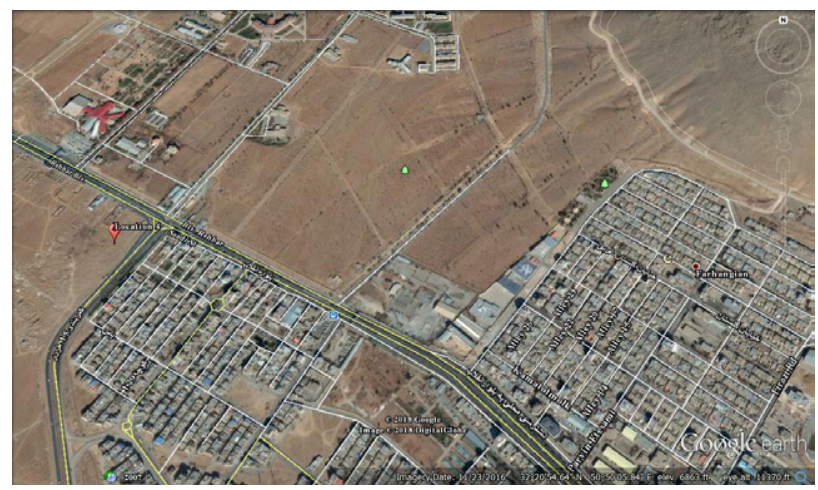

Figure 5. "Rahbar Boulevard" location

Location 5: Chahar Bagh

The location is situated close to one of the main entrances to the city and close to one of the beautiful boulevards of the city called Imam Reza.

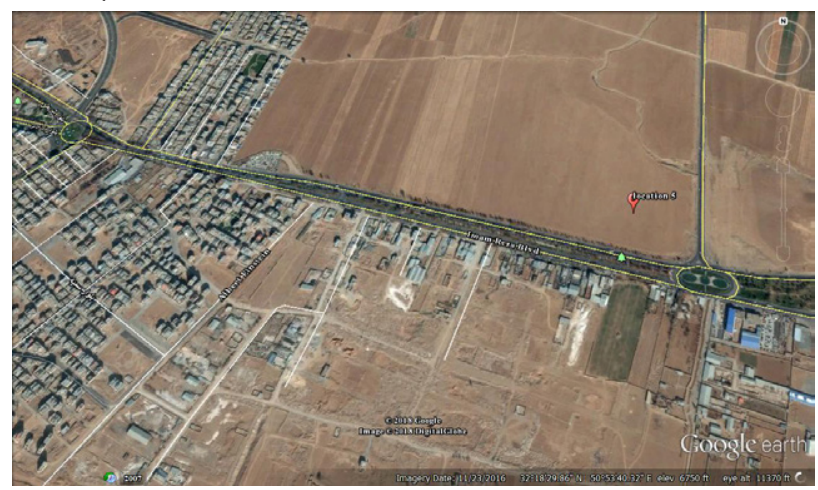

Figure 6. "Chahar Bagh" location

\subsection{Information about cooperated experts}

To have a better multi-disciplinary perspective about process of locating different fields have selected. The main experts for cooperating to the study about evaluating criteria and alternatives are from following fields: Civil Engineering, Environmental Engineering, MBA, Futures Studies, Economics and Tourism Management. The combination of experts is based on two experienced civil engineer, two environmental engineers, one MBA as an experienced manager for developing businesses, one $\mathrm{PhD}$ of Futures Studies to cover foresight perspective of the study, one $\mathrm{PhD}$ and one experienced expert of economics (two experts of economics) and finally two tourism managers with background of managing hotels. Educational background of the all experts (10 experts) is presented in Table 4 . The minimum experience of the all experts is more than seven years. Experts were involved in both calculations of BWM and WASPAS methods. 
Table 4. Educational background Information of experts

\begin{tabular}{|c|c|c|c|}
\hline & Variable & Items & No \\
\hline \multirow[t]{3}{*}{1} & \multirow[t]{3}{*}{ Civil engineering } & Bachelor & 0 \\
\hline & & Master & 1 \\
\hline & & Ph.D. & 1 \\
\hline \multirow[t]{3}{*}{2} & \multirow[t]{3}{*}{ Environmental engineering } & Bachelor & 0 \\
\hline & & Master & 1 \\
\hline & & Ph.D. & 1 \\
\hline \multirow[t]{3}{*}{3} & \multirow[t]{3}{*}{ MBA } & Bachelor & 0 \\
\hline & & Master & 1 \\
\hline & & Ph.D. & 0 \\
\hline \multirow[t]{3}{*}{4} & \multirow[t]{3}{*}{ Futures studies } & Bachelor & 0 \\
\hline & & Master & 0 \\
\hline & & Ph.D. & 1 \\
\hline \multirow[t]{3}{*}{5} & \multirow[t]{3}{*}{ Economics } & Bachelor & 1 \\
\hline & & Master & 0 \\
\hline & & Ph.D. & 1 \\
\hline \multirow[t]{3}{*}{6} & \multirow[t]{3}{*}{ Tourism managers } & Bachelor & 0 \\
\hline & & Master & 2 \\
\hline & & Ph.D. & 0 \\
\hline
\end{tabular}

\section{Results}

This section has two main parts which will be outputs of BWM and WASPAS methods to see the weight of criteria and final ranking of alternatives.

\subsection{BWM outputs}

Calculation for BWM is done in two levels because hierarchy of criteria which has two levels. The first step is evaluating main criteria and second level will be for subcriteria of each main criterion.

- There was a conference meeting and some of experts couldn't participate face to face so half of them participated online. The idea was to share the different ideas and information between experts from different fields to decrease risk of misunderstanding of different approaches and paradigms. A general agreement concluded and experts decided to think in a bigger picture of the topic.

- First step of BWM is pairwise comparisons which can be different expert to expert. Selecting the best and the worst criteria decided in the conference meeting so each expert filled the questionnaire based on the preliminary decision of the group.

Step 1: Pairwise comparison and final results and weights of main criteria are shown in Tables 5-8. Table 5 is illustrated decision making table of criteria, Table 6 is presented pairwise comparison of the best criterion to other and Table 6 is the same but for others to the worst criterion.
As it shown in Table 5, "Physical site characteristics" is selected as the best criterion from experts' perspective.

Table 6. Best criterion to other criteria

\begin{tabular}{|c|c|c|c|c|c|}
\hline Best to others & $\mathrm{C}_{1}$ & $\mathrm{C}_{2}$ & $\mathrm{C}_{3}$ & $\mathrm{C}_{4}$ & $\mathrm{C}_{5}$ \\
\hline $\mathrm{C}_{4}$ & 4 & 2 & 3 & 1 & 5 \\
\hline
\end{tabular}

Again, as it illustrated in Table 5 the worst criterion is considered as "Potential continuous development".

Table 7. Other criteria to the worst criterion

\begin{tabular}{|c|c|}
\hline Others to the worst & $\mathrm{C}_{5}$ \\
\hline $\mathrm{C}_{1}$ & 2 \\
\hline $\mathrm{C}_{2}$ & 3 \\
\hline $\mathrm{C}_{3}$ & 4 \\
\hline $\mathrm{C}_{4}$ & 5 \\
\hline $\mathrm{C}_{5}$ & 1 \\
\hline
\end{tabular}

Final weights of each main criterion are presented in Table 8.

Table 8. Final results and weights of main criteria

\begin{tabular}{|l|c|c|c|c|c|}
\hline \multirow{2}{*}{ Weights } & $\mathrm{C}_{1}$ & $\mathrm{C}_{2}$ & $\mathrm{C}_{3}$ & $\mathrm{C}_{4}$ & $\mathrm{C}_{5}$ \\
\cline { 2 - 6 } & 0.123 & 0.246 & 0.164 & 0.404 & 0.063 \\
\hline \hline Ksi $^{*}$ & 0.088 &
\end{tabular}

Consistency rate is acceptable for decision making about main criteria through decision makers' ideas.

Step 2: After decision making about main criteria and final answers for sub-criteria of cost criterion, weights for sub-criteria of Macro General Technical Features should be calculated. The procedure will be the same as main criteria and results will be demonstrated in Tables 9-12.

Table 9. Decision making table of sub-criteria for "Costs" (Main criterion)

\begin{tabular}{|c|c|c|c|}
\hline $\begin{array}{c}\text { Criteria } \\
\text { number }\end{array}$ & $\mathrm{C}_{1-1}$ & $\mathrm{C}_{1-2}$ & $\mathrm{C}_{1-3}$ \\
\hline $\begin{array}{c}\text { Names of } \\
\text { criteria }\end{array}$ & $\begin{array}{c}\text { Cost of } \\
\text { land in the } \\
\text { location }\end{array}$ & $\begin{array}{c}\text { Cost of } \\
\text { operation }\end{array}$ & $\begin{array}{c}\text { Site } \\
\text { preparation } \\
\text { cost }\end{array}$ \\
\hline
\end{tabular}

As is can be seen "Cost of land in the location" is the best sub-criterion from decision makers point of view.

Table 10. Best sub-criterion to other sub-criteria

\begin{tabular}{|c|c|c|c|}
\hline Best to others & $\mathrm{C}_{1-1}$ & $\mathrm{C}_{1-2}$ & $\mathrm{C}_{1-3}$ \\
\hline $\mathrm{C}_{1-1}$ & 1 & 3 & 2 \\
\hline
\end{tabular}

Table 5. Decision making table of criteria

\begin{tabular}{|c|l|l|l|l|l|}
\hline Criteria number & \multicolumn{1}{|c|}{$\mathrm{C}_{1}$} & \multicolumn{1}{c|}{$\mathrm{C}_{2}$} & \multicolumn{1}{c|}{$\mathrm{C}_{3}$} & \multicolumn{1}{c|}{$\mathrm{C}_{4}$} & \multicolumn{1}{c|}{$\mathrm{C}_{5}$} \\
\hline Names of criteria & Costs & $\begin{array}{l}\text { Facilities and } \\
\text { accessibility }\end{array}$ & $\begin{array}{l}\text { Access to } \\
\text { transportation }\end{array}$ & $\begin{array}{l}\text { Physical site } \\
\text { characteristics }\end{array}$ & $\begin{array}{l}\text { Potential continuous } \\
\text { development }\end{array}$ \\
\hline
\end{tabular}


As it shown in Table 9, "Site preparation cost" is selected as the worst sub-criterion in this section.

Table 11. Other criteria to the worst criterion

\begin{tabular}{|c|c|}
\hline Others to the worst & $\mathrm{C}_{1-3}$ \\
\hline $\mathrm{C}_{1-1}$ & 4 \\
\hline $\mathrm{C}_{1-2}$ & 3 \\
\hline $\mathrm{C}_{1-3}$ & 1 \\
\hline
\end{tabular}

Final weights of each sub-criterion for "Costs" are presented in Table 12.

Table 12. Final results and weights of sub-criteria

\begin{tabular}{|l|c|c|c|}
\hline \multirow{2}{*}{ Weights } & $\mathrm{C}_{1-1}$ & $\mathrm{C}_{1-2}$ & $\mathrm{C}_{1-3}$ \\
\cline { 2 - 4 } & 0.567 & 0.267 & 0.167 \\
\hline Final weights & 0.0697 & 0.0328 & 0.0205 \\
\hline Ksi $^{*}$ & 0.233 & & \\
\hline
\end{tabular}

Consistency rate is acceptable for decision making about sub-criteria of "Costs" through decision makers' ideas.
In continue, in this section, sub-criteria of "Facilities and accessibility" will be evaluated and weighted. Again, there are same procedures for the calculation. Final results will be presented in Tables 13-16.

As it highlighted, "Proximity to the city center" is selected as the best criterion from decision makers' point of view.

As it illustrated in Table 13, "Open space" is selected as the worst criterion.

Final weight of each sub-criterion is shown in Table 16.

Consistency rate is acceptable for decision making about sub-criteria of Macro General Technical Features through decision makers' ideas.

Step 3: In this section sub-criteria of Technical-Environmental Features will be evaluated and weighted. Again, there are same procedures for the calculation. Final results will be presented in Tables 17-20.

As it highlighted, "Accessibility of public transport" is selected as the best criterion from decision makers' point of view.

As it illustrated in Table 17, "Proximity to major Roads" is selected as the worst criterion.

Table 13. Decision making table of sub-criteria for "Facilities and accessibility" (Main criterion)

\begin{tabular}{|l|l|l|l|l|l|l|}
\hline Criteria number & \multicolumn{1}{|c|}{$\mathrm{C}_{2-1}$} & \multicolumn{1}{c|}{$\mathrm{C}_{2-2}$} & \multicolumn{1}{c|}{$\mathrm{C}_{2-3}$} & \multicolumn{1}{c|}{$\mathrm{C}_{2-4}$} & $\mathrm{C}_{2-5}$ & \multicolumn{1}{c|}{$\mathrm{C}_{2-6}$} \\
\hline Names of criteria & $\begin{array}{l}\text { Car parking } \\
\text { facilities (Parking } \\
\text { area) }\end{array}$ & $\begin{array}{l}\text { Proximity to } \\
\text { public facilities } \\
\text { and services }\end{array}$ & $\begin{array}{l}\text { Proximity to } \\
\text { medical facilities }\end{array}$ & $\begin{array}{l}\text { Traffic } \\
\text { convenience }\end{array}$ & $\begin{array}{l}\text { Proximity to the } \\
\text { city center }\end{array}$ & Open space \\
\hline
\end{tabular}

Table 14. Best sub-criterion to other sub-criteria

\begin{tabular}{|c|c|c|c|c|c|c|}
\hline Best to others & $\mathrm{C}_{2-1}$ & $\mathrm{C}_{2-2}$ & $\mathrm{C}_{2-3}$ & $\mathrm{C}_{2-4}$ & $\mathrm{C}_{2-5}$ & $\mathrm{C}_{2-6}$ \\
\hline $\mathrm{C}_{2-5}$ & 3 & 2 & 3 & 2 & 1 & 3 \\
\hline
\end{tabular}

Table 15. Other criteria to the worst criterion

\begin{tabular}{|c|c|}
\hline Others to the worst & $\mathrm{C}_{2-6}$ \\
\hline $\mathrm{C}_{2-1}$ & 4 \\
\hline $\mathrm{C}_{2-2}$ & 4 \\
\hline $\mathrm{C}_{2-3}$ & 3 \\
\hline $\mathrm{C}_{2-4}$ & 3 \\
\hline $\mathrm{C}_{2-5}$ & 4 \\
\hline $\mathrm{C}_{2-6}$ & 1 \\
\hline
\end{tabular}

Table 17. Decision making table of sub-criteria for "Access to transportation" (Main criterion)

\begin{tabular}{|l|l|l|l|}
\hline \multicolumn{1}{|c|}{ Criteria number } & \multicolumn{1}{|c|}{$\mathrm{C}_{3-1}$} & $\mathrm{C}_{3-2}$ & \multicolumn{1}{c|}{$\mathrm{C}_{3-3}$} \\
\hline Names of criteria & Closeness to the airport & Proximity to major roads & Accessibility of public transport \\
\hline
\end{tabular}

Table 18. Best sub-criterion to other sub-criteria

\begin{tabular}{|c|c|c|c|}
\hline Best to others & $\mathrm{C}_{3-1}$ & $\mathrm{C}_{3-2}$ & $\mathrm{C}_{3-3}$ \\
\hline $\mathrm{C}_{3-3}$ & 2 & 4 & 1 \\
\hline
\end{tabular}

Table 16. Final results and weights of sub-criteria

\begin{tabular}{|c|c|c|c|c|c|c|}
\hline \multirow{2}{*}{ Weights } & $\mathrm{C}_{2-1}$ & $\mathrm{C}_{2-2}$ & $\mathrm{C}_{2-3}$ & $\mathrm{C}_{2-4}$ & $\mathrm{C}_{2-5}$ & $\mathrm{C}_{2-6}$ \\
\cline { 2 - 7 } & 0.131 & 0.196 & 0.131 & 0.196 & 0.286 & 0.060 \\
\hline Final weights & 0.032 & 0.048 & 0.032 & 0.048 & 0.070 & 0.015 \\
\hline
\end{tabular}

\begin{tabular}{|l|l|}
\hline Ksi $^{*}$ & 0.107 \\
\hline
\end{tabular}


Final weight of each sub-criterion is shown in Table 20.

Table 20. Final results and weights of sub-criteria

\begin{tabular}{|c|c|c|c|}
\hline \multirow{2}{*}{ Weights } & $\mathrm{C}_{3-1}$ & $\mathrm{C}_{3-2}$ & $\mathrm{C}_{3-3}$ \\
\cline { 2 - 4 } & 0.344 & 0.125 & 0.531 \\
\hline Final weights & 0.093 & 0.044 & 0.027 \\
\hline
\end{tabular}

$\mathrm{Ksi}^{*}$

0.156

Consistency rate is acceptable for decision making about sub-criteria of Technical-Environmental Features through decision makers' ideas.

- Criterion 4 (Physical site characteristics) and criterion 5 (Potential continuous development) have only two sub-criteria which mean they don't need any calculation for the process of finding their weights. For the sub-criteria of "Physical site characteristics", "View (Good scenery)" took 0.667 percentage of the weight of the main criterion and "Outdoor noise" gained 0.333 of the percentage. So, final weight of "View (Good scenery)" should be 0.269 and "Out- door noise" finally will be 0.135 . Based on experts' opinions, relative importance of sub-criteria of "Potential continuous development" is the same so final weights for both "Opportunity to expand the hotel in future" and "Closeness to other hotels already existed nearby" will be the same and 0.0315 .

\subsection{WASPAS outputs}

Results and final ranking of alternatives as locations are presented here from Tables 20-23. Decision making matrix is prepared based on both real data and qualitative data based on experts' opinions about the quality of locations in facing with the criteria. Decision making matrix is presented below as Table 21 .

- In prioritizing and ranking of alternatives (locations) based on WASPAS both real data and experts' opinions have been considered. The normal average (rounding numbers) instead of decimals is used and applied in the Table 21.

Based on the methodology normalized weighted decision making matrix should prepare in both summarizing and multiplication parts which can be seen in Tables 22-23.

Table 21. Decision making matrix

\begin{tabular}{|c|c|c|c|c|c|c|c|c|c|c|c|c|c|c|c|c|}
\hline & \multicolumn{3}{|c|}{$\mathrm{C}_{1}$} & \multicolumn{6}{|c|}{$\mathrm{C}_{2}$} & \multicolumn{3}{|c|}{$\mathrm{C}_{3}$} & \multicolumn{2}{|c|}{$\mathrm{C}_{4}$} & \multicolumn{2}{|c|}{$\mathrm{C}_{5}$} \\
\hline & $\mathrm{C}_{1-1}$ & $\mathrm{C}_{1-2}$ & $\mathrm{C}_{1-3}$ & $\mathrm{C}_{2-1}$ & $\mathrm{C}_{2-2}$ & $\mathrm{C}_{2-3}$ & $\mathrm{C}_{2-4}$ & $\mathrm{C}_{2-5}$ & $\mathrm{C}_{2-6}$ & $\mathrm{C}_{3-1}$ & $\mathrm{C}_{3-2}$ & $\mathrm{C}_{3-3}$ & $\mathrm{C}_{4-1}$ & $\mathrm{C}_{4-2}$ & $\mathrm{C}_{5-1}$ & $\mathrm{C}_{5-2}$ \\
\hline & Min & Min & Min & Max & Max & Max & Max & Max & Max & $\operatorname{Max}$ & Max & Max & Max & Min & $\operatorname{Max}$ & Min \\
\hline & 0.0697 & 0.0328 & 0.0205 & 0.032 & 0.048 & 0.032 & 0.048 & 0.070 & 0.015 & 0.093 & 0.044 & 0.027 & 0.269 & 0.135 & 0.0315 & 0.0315 \\
\hline Unit & $\$ / \mathrm{m}^{2}$ & Q & Q & $\mathrm{Q}$ & Q & Q & Q & $\mathrm{km}$ & Q & $\mathrm{km}$ & Q & Q & Q & Q & $\begin{array}{l}\% \text { of } \\
\text { land }\end{array}$ & Q \\
\hline$\overline{A_{1}}$ & 600 & 3 & 2 & 9 & 8 & 8 & 9 & 4 & 8 & 12 & 8 & 8 & 7 & 2 & 30 & 3 \\
\hline $\mathrm{A}_{2}$ & 200 & 6 & 4 & 8 & 3 & 9 & 9 & 4 & 8 & 9 & 4 & 2 & 6 & 1 & 30 & 7 \\
\hline $\mathrm{A}_{3}$ & 400 & 4 & 2 & 7 & 7 & 6 & 4 & 1.5 & 6 & 6 & 7 & 8 & 6 & 6 & 10 & 2 \\
\hline $\mathrm{A}_{4}$ & 300 & 5 & 2 & 7 & 5 & 3 & 4 & 7 & 5 & 8 & 8 & 8 & 7 & 5 & 15 & 2 \\
\hline $\mathrm{A}_{5}$ & 300 & 3 & 2 & 9 & 6 & 5 & 6 & 5.5 & 8 & 11 & 9 & 5 & 8 & 5 & 30 & 3 \\
\hline
\end{tabular}

* $\mathrm{Q}=$ Qualitative.

Table 22. Normalized weighted decision making matrix for summarizing part

\begin{tabular}{|c|c|c|c|c|c|c|c|c|c|c|c|c|c|c|c|c|}
\hline & \multicolumn{3}{|c|}{$\mathrm{C}_{1}$} & \multicolumn{6}{|c|}{$\mathrm{C}_{2}$} & \multicolumn{3}{|c|}{$\mathrm{C}_{3}$} & \multicolumn{2}{|c|}{$\mathrm{C}_{4}$} & \multicolumn{2}{|c|}{$\mathrm{C}_{5}$} \\
\hline & $\mathrm{C}_{1-1}$ & $\mathrm{C}_{1-2}$ & $\mathrm{C}_{1-3}$ & $\mathrm{C}_{2-1}$ & $\mathrm{C}_{2-2}$ & $\mathrm{C}_{2-3}$ & $\mathrm{C}_{2-4}$ & $\mathrm{C}_{2-5}$ & $\mathrm{C}_{2-6}$ & $\mathrm{C}_{3-1}$ & $\mathrm{C}_{3-2}$ & $\mathrm{C}_{3-3}$ & $\mathrm{C}_{4-1}$ & $\mathrm{C}_{4-2}$ & $\mathrm{C}_{5-1}$ & $\mathrm{C}_{5-2}$ \\
\hline $\mathrm{A}_{1}$ & 0.023 & 0.033 & 0.021 & 0.032 & 0.048 & 0.028 & 0.048 & 0.040 & 0.015 & 0.093 & 0.044 & 0.027 & 0.235 & 0.068 & 0.032 & 0.021 \\
\hline $\mathrm{A}_{2}$ & 0.070 & 0.016 & 0.010 & 0.028 & 0.018 & 0.032 & 0.048 & 0.040 & 0.015 & 0.070 & 0.022 & 0.007 & 0.202 & 0.135 & 0.032 & 0.009 \\
\hline $\mathrm{A}_{3}$ & 0.035 & 0.025 & 0.021 & 0.025 & 0.042 & 0.021 & 0.021 & 0.015 & 0.011 & 0.047 & 0.039 & 0.027 & 0.202 & 0.023 & 0.011 & 0.032 \\
\hline $\mathrm{A}_{4}$ & 0.046 & 0.020 & 0.021 & 0.025 & 0.030 & 0.011 & 0.021 & 0.070 & 0.009 & 0.062 & 0.044 & 0.027 & 0.235 & 0.027 & 0.016 & 0.032 \\
\hline $\mathrm{A}_{5}$ & 0.046 & 0.033 & 0.021 & 0.032 & 0.036 & 0.018 & 0.032 & 0.055 & 0.015 & 0.085 & 0.044 & 0.017 & 0.269 & 0.027 & 0.032 & 0.021 \\
\hline
\end{tabular}

Table 23. Normalized weighted decision making matrix for multiplication part

\begin{tabular}{|c|c|c|c|c|c|c|c|c|c|c|c|c|c|c|c|c|}
\hline & \multicolumn{3}{|c|}{$\mathrm{C}_{1}$} & \multicolumn{6}{|c|}{$\mathrm{C}_{2}$} & \multicolumn{3}{|c|}{$\mathrm{C}_{3}$} & \multicolumn{2}{|c|}{$\mathrm{C}_{4}$} & \multicolumn{2}{|c|}{$\mathrm{C}_{5}$} \\
\hline & $\mathrm{C}_{1-1}$ & $\mathrm{C}_{1-2}$ & $\mathrm{C}_{1-3}$ & $\mathrm{C}_{2-1}$ & $\mathrm{C}_{2-2}$ & $\mathrm{C}_{2-3}$ & $\mathrm{C}_{2-4}$ & $\mathrm{C}_{2-5}$ & $\mathrm{C}_{2-6}$ & $\mathrm{C}_{3-1}$ & $\mathrm{C}_{3-2}$ & $\mathrm{C}_{3-3}$ & $\mathrm{C}_{4-1}$ & $\mathrm{C}_{4-2}$ & $\mathrm{C}_{5-1}$ & $\mathrm{C}_{5-2}$ \\
\hline$A_{1}$ & 0.926 & 1.000 & 1.000 & 1.000 & 1.000 & 0.996 & 1.000 & 0.962 & 1.000 & 1.000 & 1.000 & 1.000 & 0.965 & 0.911 & 1.000 & 0.987 \\
\hline $\mathrm{A}_{2}$ & 1.000 & 0.978 & 0.986 & 0.996 & 0.954 & 1.000 & 1.000 & 0.962 & 1.000 & 0.974 & 0.970 & 0.963 & 0.926 & 1.000 & 1.000 & 0.961 \\
\hline $\mathrm{A}_{3}$ & 0.953 & 0.991 & 1.000 & 0.992 & 0.994 & 0.987 & 0.962 & 0.898 & 0.996 & 0.938 & 0.994 & 1.000 & 0.926 & 0.785 & 0.966 & 1.000 \\
\hline $\mathrm{A}_{4}$ & 0.972 & 0.983 & 1.000 & 0.992 & 0.978 & 0.965 & 0.962 & 1.000 & 0.993 & 0.963 & 1.000 & 1.000 & 0.965 & 0.805 & 0.978 & 1.000 \\
\hline$A_{5}$ & 0.972 & 1.000 & 1.000 & 1.000 & 0.986 & 0.981 & 0.981 & 0.983 & 1.000 & 0.992 & 1.000 & 0.987 & 1.000 & 0.805 & 1.000 & 0.987 \\
\hline
\end{tabular}


Final ranking of locations is presented in Table 24 .

Table 24. The results of WASPAS

\begin{tabular}{|c|c|c|c|c|}
\hline & $0.5 \sum_{j=1}^{n} \overline{\bar{X}} i j$, sum & $0.5 \prod_{j=1}^{n} \overline{\bar{X}} i j$, mult & WSP & Ranking \\
\hline $\mathrm{A}_{1}$ & 0.404 & 0.385 & 0.789 & 1 \\
\hline $\mathrm{A}_{2}$ & 0.377 & 0.356 & 0.733 & 3 \\
\hline $\mathrm{A}_{3}$ & 0.297 & 0.258 & 0.555 & 5 \\
\hline $\mathrm{A}_{4}$ & 0.348 & 0.313 & 0.660 & 2 \\
\hline $\mathrm{A}_{5}$ & 0.391 & 0.353 & 0.744 & 4 \\
\hline
\end{tabular}

As it can be seen Location 1, East Ayatollah Kashani Boulevard, ranked as the best location for building a five star hotel and it seems the most feasible, sustainable and tourist absorbing place in mentioned locations.

\section{Conclusion and discussion}

Undoubtedly, determining an appropriate and strategic location is an indispensable part of the development of a successful business and it can be evolved a business sector.

Nowadays, with the dramatic growth of demand for high quality hotels in the tourism industry, developing an effective and systemic strategy in hotel development is a significant matter. Consequently, decision making for choosing the best location for the hotel is one of the essential as well as awkward stages in hotel development projects. The hotel locating involves multi-dimensional factors which make the process of decision making highly complex and needs an integrated system for strengthening and enhancing the process.

This research presented a novel comprehensive approach for hotel locating based on new hybrid MADM methods and sustainability perspective. Locating should be based on both current and future factors to ensure that the selected site is not only the best choice for today but also beneficial for the hotel industry in the future. Therefore, the methodology of the research has been chosen logically and in accordance with a foresight perspective. From authors' point of view, integrated method of using BWM for criteria evaluation and WASPAS for ranking the alternatives can be one of the best analytical approaches to evaluate and assess hotel's locations, as alternatives, based on the criteria in the effective and efficient way. This approach has applied to the real case study of hotel location selection in Shahrekord, Iran, which its truism industry is in a growing trend.

On the other hand, in such cities like Shahrekord, the infrastructural planning have not followed a stable model for decision-making process which caused serious conflict for investors and planners especially in large scale projects such as hotel construction. Tourist hotel locating involves complex decision making systems that require efficient tools to deal with the decision challenges. The proposed methodology in this study can be efficiently used as an analytical model for tackling planning and managing challenges for location selection.

In the competitive nature of the hotel sector, the result of this research provides valuable and useful information for investors, hotel owners, and urban planners. Additionally, it contributes to the sustainable development of tourism since hotels are the core sector of the tourism industry.

Hotels are the major and largest sector of the hospitality industry which have significant impacts on the environment as well as social and economic dimensions. Sustainability subjects will have positive effects on tourist's experiences and attraction, reduce costs, and protect the environment. In long-term planning, urban planners and decision makers should, basically, apply sustainability throughout all stages of decision-making process. Due to the profound environmental impacts of hotel construction, and as one of the crucial stages of hotel development, locating should be analyzed and evaluated based on sustainability factors. The efficient outcomes will be achieved through investing in better development procedures. Owing to the critical importance of sustainability, in this research, choosing the candidate sites as well as the criteria are based on sustainability perspective.

In this study, the five candidate locations are in places with low potential to make pollutions during the hotel operation and with high potential to develop a green hotel in the area. The possible and existing environmental considerations for selected sites have been investigated in order to have the least environmental impacts. Besides, candidate locations are close to major roads and facilities which reduce the cost of the hotel operation as well as the pollution dramatically. Essential social dimensions have also considered in the selection of the factors and criteria such as the safety of the sites and the availability of public and medical facilities.

According to the BMW used in the research by using of pairwise comparison based on experts' opinions, the main criteria of physical site characteristics (C4) achieve the highest weight between five main criteria and the $\mathrm{C}_{4-1}$ view (good scenery) gain the highest weight among the sub-criteria. 
In comparison to some other studies such as Hashemkhani Zolfani et al. (2013) and Popovic et al. (2019) in locating related issues there is a big difference in the methodology. These studies both applied SWARA method for evaluating and weighting criteria while this study applied BWM to do that. These two methods are basically different but the main point is the core idea. SWARA is a policy based method for weighting criteria (Hashemkhani Zolfani \& Saparauskas, 2013) while BWM is new version of pairwise comparison based methods. This study is not organized on some policies so decided to analyze criteria based on their nature and relationship. Xiaomei, Ming, Huchang, Wenjing, and Lev (2019) presented a literature review on BWM and its applications. Based on this research, greatly referred which BWM in comparison to AHP is more powerful and has less inconsistency.

The findings of the research on a five-star hotel locating in Shahrekord support that "location 1" should be chosen for developing a high quality hotel by considering sustainability view. The result shows that this location will be an excellent choice for Shahrekord to promote the sustainable tourism industry in both current and prospective future. There was a limitation in this study and it was some locations with unknown situation which they didn't have proper documents to show who or organization is the exact owner of that location and in charge of them. The contribution of the study is the application of the combination of sustainability perspective and MADM framework which can practically apply in the future locating projects.

\section{References}

Adam, I., \& Amuquandoh, F. E. (2013). Dimensions of hotel location in the Kumasi Metropolis, Ghana. Tourism Management Perspectives, 8, 1-8. https://doi.org/10.1016/j.tmp.2013.05.003

Aksoy, S., \& Yetkin Ozbuk, M. (2017). Multiple criteria decision making in hotel location: does it relate to postpurchase consumer evaluations? Tourism Management Perspectives, 22, 73-81. https://doi.org/10.1016/j.tmp.2017.02.001

Amjad Alam, K., Ahmed, R., Shafique Butt, F., Kim, S. G., \& Ko, K. M. (2018). An uncertainty-aware integrated fuzzy AHP-WASPAS model to evaluate public cloud computing services. Procedia Computer Science, 130, 504-509.

https://doi.org/10.1016/j.procs.2018.04.068

Amoozad Mahdiraji, H., Arzaghi, S., Stauskis, G., \& Zavadskas, E. K. (2018). A hybrid fuzzy BWM-COPRAS method for analyzing key factors of sustainable architecture. Sustainability, 10(5), 1626. https://doi.org/10.3390/su10051626

Azouz, M., \& Galal, A. (2016). Sustainable site assessment: a way to sustainable hospitality in Egypt. Procedia Environmental Sciences, 34, 360-374.

https://doi.org/10.1016/j.proenv.2016.04.032

Badri Ahmadi, H., Kusi-Sarpong, S., \& Rezaei, J. (2017). Assessing the social sustainability of supply chains using Best Worst Method. Resources, Conservation and Recycling, 126, 99-106. https://doi.org/10.1016/j.resconrec.2017.07.020

Bagocius, V., Zavadskas, E. K., \& Turskis, Z. (2014). Selecting a location for a liquefied natural gas terminal in the Eastern Baltic Sea. Transport, 29(1), 69-74.

https://doi.org/10.3846/16484142.2014.897996
Balezentis, T., \& Streimikiene, D. (2018). Multi-criteria ranking of energy generation scenarios with Monte Carlo simulation. Applied Energy, 185(Part 1), 862-871.

https://doi.org/10.1016/j.apenergy.2016.10.085

Bausys, R., \& Juodagalviene, B. (2017). Garage location selection for residential house by WASPAS-SVNS method. Journal of Civil Engineering and Management, 23(3), 421-429. https://doi.org/10.3846/13923730.2016.1268645

Bielinskas, V., Burinskienè, M., \& Palevičius, V. (2015). Assessment of neglected areas in Vilnius city using MCDM and COPRAS methods. Procedia Engineering, 122, 29-38.

https://doi.org/10.1016/j.proeng.2015.10.004

Bonenberg, W., \& Kaplinski, O. (2018). The architect and the paradigms of sustainable development: a review of dilemmas. Sustainability, 10(1), 100. https://doi.org/10.3390/su10010100

Chan, E. S. W., \& Wong, S. C. K. (2006). Hotel selection: when price is not the issue. Journal of Vacation Marketing, 12(2), 142-159. https://doi.org/10.1177/1356766706062154

Cheng, E. W. L., Li, H., \& Yu, L. (2005). The Analytic Network Process (ANP) approach to location selection: a shopping mall illustration. Construction Innovation, 5(2), 83-97. https://doi.org/10.1108/14714170510815195

Chitsaz, N., \& Azarivand, A. (2016). Water scarcity management in arid regions based on an extended multiple criteria technique. Water Resources Management, 31(1), 233-250. https://doi.org/10.1007/s11269-016-1521-5

Chou, T. Y., Hsu, C. L., \& Chen, M. C. (2008). A fuzzy multi-criteria decision model for international tourist hotels location selection. International Journal of Hospitality Management, 27(2), 293-301. https://doi.org/10.1016/j.ijhm.2007.07.029

Chu, R. K. S., \& Choi, T. (2000). An importance-performance analysis of hotel selection factors in the Hong Kong hotel industry: a comparison of business and leisure travellers. Tourism Management, 21(4), 363-377.

https://doi.org/10.1016/S0261-5177(99)00070-9

Devici, M., Canitez, F., \& Gokasar, I. (2018). WASPAS and TOPSIS based interval type-2 fuzzy MCDM method for a selection of a car sharing station. Sustainable Cities and Society, 41, 777-791. https://doi.org/10.1016/j.scs.2018.05.034

Dweiri, F., Ahmed Khan, S., \& Almulla, A. (2018). A multi-criteria decision support system to rank sustainable desalination plant location criteria. Desalination, 444, 26-34. https://doi.org/10.1016/j.desal.2018.07.007

Ekinci, Y., Prokopaki, P., \& Cobanoglu, C. (2003). Service quality in Cretan accommodations: marketing strategies for the UK holiday market. International Journal of Hospitality Management, 22(1), 47-66. https://doi.org/10.1016/S0278-4319(02)00072-5

Elzarka, H. M., Yan, H., \& Chakraborty, D. (2017). A vague set fuzzy multi-attribute group decision-making model for selecting onsite renewable energy technologies for institutional owners of constructed facilities. Sustainable Cities and Society, 35, 430-439. https://doi.org/10.1016/j.scs.2017.08.025

Erol, I., Sencer, S., Ozmen, A., \& Searly, C. (2014). Fuzzy MCDM framework for locating a nuclear power plant in Turkey. Energy Policy, 67, 186-197. https://doi.org/10.1016/j.enpol.2013.11.056

Esmaelian, M., Tavana, M., Santos Arteaga, F. J., \& Mohammadi, S. (2015). A multicriteria spatial decision support system for solving emergency service station location problems. International Journal of Geographical Information Science, 29(7), 1187-1213. https://doi.org/10.1080/13658816.2015.1025790

Fetanat, A., \& Khorasaninejad, E. (2015). A novel hybrid MCDM approach for offshore wind farm site selection: a case study of Iran. Ocean \& Coastal Management, 109, 17-28. https://doi.org/10.1016/j.ocecoaman.2015.02.005 
Gigović, L., Pamučar, D., Božanić, D., \& Ljubojević, S. (2017). Application of the GIS-DANP-MABAC multi-criteria model for selecting the location of wind farms: a case study of Vojvodina, Serbia. Renewable Energy, 103, 501-521.

https://doi.org/10.1016/j.renene.2016.11.057

Ginevičius, R. (2011). A new determining method for the criteria weights in multi-criteria evaluation. International Journal of Information Technology \& Decision Making, 10(6), 1067-1095. https://doi.org/10.1142/S0219622011004713

Godinho, P., Phillips, P., \& Moutinho, L. (2018). Hotel location when competitors may react: a game-theoretic gravitational model. Tourism Management, 69, 384-396.

https://doi.org/10.1016/j.tourman.2018.06.014

Gupta, H., \& Barua, M. K. (2016). Identifying enablers of technological innovation for Indian MSMEs using best-worst multi criteria decision making method. Technological Forecasting and Social Change, 107, 69-79. https://doi.org/10.1016/j.techfore.2016.03.028

Hanai, T., Oguchi, T., Ando, K., \& Yamaguchi, K. (2008). Important attributes of lodgings to gain repeat business: a comparison between individual travels and group travels. International Journal of Hospitality Management, 27(2), 268-275. https://doi.org/10.1016/j.ijhm.2007.08.006

Haghnazar Kouchaksaraei, R., Hashemkhani Zolfani, S., \& Golabchi, M. (2015). Glasshouse locating based on SWARACOPRAS approach. International Journal of Strategic Property Management, 19(2), 111-122.

https://doi.org/10.3846/1648715X.2015.1004565

Hashemkhani Zolfani, S., Aghdaie, M. H., Derakhti, A., Zavadskas, E. K., \& Morshed Varzandeh, M. H. (2013). Decision making on business issues with foresight perspective; an application of new hybrid MCDM model in shopping mall locating. Expert Systems with Applications, 40(17), 7111-7121. https://doi.org/10.1016/j.eswa.2013.06.040

Hashemkhani Zolfani, S., \& Chatterjee, P. (2019). Comparative evaluation of sustainable design based on Step-Wise Weight Assessment Ratio Analysis (SWARA) and Best Worst Method (BWM) methods: a perspective on household furnishing materials. Symmetry, 11(1), 74.

https://doi.org/10.3390/sym11010074

Hashemkhani Zolfani, S., \& Safaei Ghadikolaei, A. (2012). Application of MCDM methods in short-term planning for private universities based on balanced scorecard: a case study from Iran. International Journal of Productivity and Quality Management, 10(2), 250-266.

https://doi.org/10.1504/IJPQM.2012.048299

Hashemkhani Zolfani, S., \& Saparauskas, J. (2013). New application of SWARA method in prioritizing sustainability assessment indicators of energy system. Inzinerine EkonomikaEngineering Economics, 24(5), 408-414.

https://doi.org/10.5755/j01.ee.24.5.4526

Hashemkhani Zolfani, S., Sedaghat, M., Maknoon, R., \& Zavadskas, E. K. (2015). Sustainable tourism: a comprehensive literature review on frameworks and applications. Economic Research-Ekonomska Istraživanja, 28(1), 1-30. https://doi.org/10.1080/1331677X.2014.995895

Hashemkhani Zolfani, S., Maknoon, R., \& Zavadskas, E. K. (2016). An introduction to prospective multiple attribute decision making (PMADM). Technological and Economic Development of Economy, 22(2), 309-326.

https://doi.org/10.3846/20294913.2016.1150363

Hashemkhani Zolfani, S., Pourhossein, M., Yazdani, M., \& Zavadskas, E. K. (2018a). Evaluating construction projects of hotels based on environmental sustainability with MCDM framework. Alexandria Engineering Journal, 57(1), 121-130. https://doi.org/10.1016/j.aej.2016.11.002

Hashemkhani Zolfani, S., Yazdani, M., \& Zavadskas, E. K. (2018b). An extended stepwise weight assessment ratio analysis (SWARA) method for improving criteria prioritization process. Soft Computing, 22(22), 7399-7405.

https://doi.org/10.1007/s00500-018-3092-2

Hashemkhani Zolfani, S., Zavadskas, E. K., Khazaelpour, P., \& Cavallaro, F. (2018c). The multi-aspect criterion in the PMADM outline and its possible application to sustainability assessment. Sustainability, 10(12), 4451.

https://doi.org/10.3390/su10124451

Hsieh, L. F., Lin, L. H., \& Lin, Y. Y. (2008). A service quality measurement architecture for hot spring hotels in Taiwan. Tourism Management, 29(3), 429-438.

https://doi.org/10.1016/j.tourman.2007.05.009

Kabak, M., Erbas, M., Cetinkaya, C., \& Ozceylan, E. (2018). A GIS-based MCDM approach for the evaluation of bike-share stations. Journal of Cleaner Production, 201, 49-60.

https://doi.org/10.1016/j.jclepro.2018.08.033

Karabašević, D., Stanujkić, D., Urošević, S., \& Maksimović, M. (2016). An approach to personnel selection based on SWARA and WASPAS methods. Journal of Economics, Management and Informatics, 7(1), 1-11. https://doi.org/10.5937/bizinfo1601001K

Keršuliene, V., Zavadskas, E. K., \& Turskis, Z. (2010). Selection of rational dispute resolution method by applying new stepwise weight assessment ratio analysis (SWARA). Journal of Business Economics and Management, 11(2), 243-258. https://doi.org/10.3846/jbem.2010.12

Khodadadi, M. R., Hashemkhani Zolfani, S., Yazdani, M., \& Zavadskas, E. K. (2017). A hybrid MADM analysis in evaluating process of chemical wastewater purification regarding to advance oxidation processes. Journal of Environmental Engineering and Landscape Management, 25(3), 277-288.

https://doi.org/10.3846/16486897.2017.1281140

Komchornrit, K. (2017). The selection of dry port location by a hybrid CFA-MACBETH-PROMETHEE method: a case study of Southern Thailand. The Asian Journal of Shipping and Logistics, 33(3), 141-153. https://doi.org/10.1016/j.ajsl.2017.09.004

Lado-Sestayo, R., Vivel-Búa, M., \& Otero-González, L. (2016). Survival in the lodging sector: an analysis at the firm and location levels. International Journal of Hospitality Management, 59, 19-30. https://doi.org/10.1016/j.ijhm.2016.08.005

Lee, K. W., Kim, H. B., Kim, H. S., \& Lee, D. S. (2010). The determinants of factors in FIT guests' perception of hotel location. Journal of Hospitality and Tourism Management, 17(1), 167-174. https://doi.org/10.1375/jhtm.17.1.167

Lowe, L. S., \& Kruger, A. (1991). Motel advertising: practices and themes. International Journal of Contemporary Hospitality Management, 3(1), 17-21. https://doi.org/10.1108/09596119110001449

Luo, H., \& Yang, Y. (2016). Intra-metropolitan location choice of star-rated and non-rated budget hotels: the role of agglomeration economies. International Journal of Hospitality Management, 59, 72-83. https://doi.org/10.1016/j.ijhm.2016.09.007

Manupati, V. K., Ramkumar, M., \& Samanta, D. (2018). A multicriteria decision making approach for the urban renewal in Southern India. Sustainable Cities and Society, 42, 471-481. https://doi.org/10.1016/j.scs.2018.08.011

Mardani, A., Nilashi, M., Zakuan, N., Loganathan, N., Soheilirad, S., Mat Saman, M. Z., \& Ibrahim, O. (2017). A systematic review and meta-analysis of SWARA and WASPAS methods: theory and applications with recent fuzzy developments. Applied Soft Computing, 57, 265-292. https://doi.org/10.1016/j.asoc.2017.03.045 
Marques, S. C. R., Ferreira, F. A. F., Meidute-Kavaliauskienè, I., \& Banaitis, A. (2018). Classifying urban residential areas based on their exposure to crime: a constructivist approach. Sustainable Cities and Society, 39, 418-429.

https://doi.org/10.1016/j.scs.2018.03.005

Medlik, S. (1993). Market feasibility approach to hotel location. Tourism Review, 21(4), 141-148. https://doi.org/10.1108/eb057558

Nawaz, F., Rajabi Asadabadi, M., Khalid Janjua, N., Khadeer Hussain, O., Chang, E., \& Saberi, M. (2018). An MCDM method for cloud service selection using a Markov chain and the best-worst method. Knowledge-Based Systems, 159, 120131. https://doi.org/10.1016/j.knosys.2018.06.010

Niñerola, A., Sánchez-Rebull, M. V., \& Hernández-Lara, A. B. (2019). Tourism research on sustainability: a bibliometric analysis. Sustainability, 11(5), 1377. https://doi.org/10.3390/su11051377

Omrani, H., Alizadeh, A., \& Amini, M. (2019). A new approach based on BWM and MULTIMOORA methods for calculating semi-human development index: an application for provinces of Iran. Socio-Economic Planning Sciences (in press). https://doi.org/10.1016/j.seps.2019.02.004

Oppermann, M., \& Brewer, K. P. (1996). Location decision making in hospitality using GIS - a paradigm shift? In Proceedings from the Australian Tourism and Hospitality Research Conference (p. 272). Canberra, Australia.

Ozdemir, S., \& Sahin, G. (2018). Multi-criteria decision-making in the location selection for a solar PV power plant using AHP. Measurement, 129, 218-226. https://doi.org/10.1016/j.measurement.2018.07.020

Pamucar, D., Chatterjee, K., \& Zavadskas, E. K. (2019). Assessment of third-party logistics provider using multi-criteria decision-making approach based on interval rough numbers. Computers \& Industrial Engineering, 127, 383-407.

https://doi.org/10.1016/j.cie.2018.10.023

Popovic, G., Stanujkic, D., Brzakovic, M., \& Karabasevic, D. (2019). A multiple-criteria decision-making model for the selection of a hotel location. Land Use Policy, 84, 49-58. https://doi.org/10.1016/j.landusepol.2019.03.001

Ray, A., De, A., \& Dan, P. K. (2015). Facility location selection using complete and partial ranking MCDM methods. International Journal of Industrial and Systems Engineering, 19(2), 262-276. https://doi.org/10.1504/IJISE.2015.067251

Ren, J., Liang, H., \& Chan, F. T. S. (2017). Urban sewage sludge, sustainability, and transition for Eco-City: multi-criteria sustainability assessment of technologies based on best-worst method. Technological Forecasting \& Social Change, 116, 2939. https://doi.org/10.1016/j.techfore.2016.10.070

Rezaei, J. (2015). Best-worst multi-criteria decision-making method. Omega, 53, 49-57. https://doi.org/10.1016/j.omega.2014.11.009

Rezaei, J., Wang, J., \& Tavasszy, L. A. (2015). Linking Supplier development to supplier segmentation using Best Worst Method. Expert Systems with Applications, 42, 9152-9164. https://doi.org/10.1016/j.eswa.2015.07.073

Rezaei, J. (2016). Best-worst multi-criteria decision-making method: some properties and a linear model. Omega, 62, 126130. https://doi.org/10.1016/j.omega.2015.12.001

Rezaei, J., Hemmes, A., \& Tavasszy, L. A. (2017). Multi-criteria decision-making for complex bundling configurations in surface transportation of air freight. Journal of Air Transport Management, 61, 95-105.

https://doi.org/10.1016/j.jairtraman.2016.02.006
Rezaei, J., van Roekel, W. S., \& Tavasszy, L. A. (2018). Measuring the relative importance of the logistics performance index indicators using Best Worst Method. Transport Policy, 68, 158169. https://doi.org/10.1016/j.tranpol.2018.05.007

Saaty, T. L. (1980). The analytic hierarchy process. New York: McGraw-Hill. https://doi.org/10.21236/ADA214804

Saaty, T. L. (1996). Decision making with dependence and feedback: the analytic network process. Pittsburgh: RWS Publications.

Salimi, N., \& Rezaei, J. (2016). Measuring efficiency of university-industry Ph.D. projects using best worst method. Scientometrics, 109(3), 1911-1938.

https://doi.org/10.1007/s11192-016-2121-0

Salimi, N., \& Rezaei, J. (2018). Evaluating firms' R\&D performance using best worst method. Evaluation and Program Planning, 66, 147-155.

https://doi.org/10.1016/j.evalprogplan.2017.10.002

Sennaroglu, B., \& Celebi, G. V. (2018). A military airport location selection by AHP integrated PROMETHEE and VIKOR methods. Transportation Research Part D: Transport and Environment, 59, 160-173.

https://doi.org/10.1016/j.trd.2017.12.022

Shoval, N., McKercher, B., Ng, E., \& Birenboim, A. (2011). Hotel location and tourist activity in cities. Annals of Tourism Research, 38(4), 1594-1612.

https://doi.org/10.1016/j.annals.2011.02.007

Si, J., \& Marjanovic-Halburd, L. (2018). Criteria weighting for green technology selection as part of retrofit decision making process for existing non-domestic buildings. Sustainable Cities and Society, 41, 625-638. https://doi.org/10.1016/j.scs.2018.05.051

Stojic, G., Stevic, Z., Antucheviciene, J., Pamucar, D., \& Vasiljevic, M. (2018). A novel rough WASPAS approach for supplier selection in a company manufacturing PVC carpentry products. Information, 9(121), 1-16. https://doi.org/10.3390/info9050121

Tadic, S., Zecevic, S., \& Krstic, M. (2014). A novel hybrid MCDM model based on fuzzy DEMATEL, fuzzy ANP and fuzzy VIKOR for city logistics concept selection. Expert Systems with Applications, 41(18), 8112-8128. https://doi.org/10.1016/j.eswa.2014.07.021

Tavana, M., Santos Arteaga, F. J., Mohammadi, S., \& Alimohammadi, M. (2017). A fuzzy multi-criteria spatial decision support system for solar farm location planning. Energy Strategy Reviews, 18, 93-105. https://doi.org/10.1016/j.esr.2017.09.003

Van de Kaa, G., Janssen, M., \& Rezaei, J. (2018). Standards battles for business-to-government data exchange: identifying success factors for standard dominance using the Best Worst Method. Technological Forecasting and Social Change, 137, 182-189. https://doi.org/10.1016/j.techfore.2018.07.041

Vafaeipour, M., Hashemkhani Zolfani, S., Morshed Varzandeh, M. H., Derakhti, A., \& Keshavarz Eshkalag, M. (2014). Assessment of regions priority for implementation of solar projects in Iran: new application of a hybrid multi-criteria decision making approach. Energy Conversion and Management, 86, 653-663. https://doi.org/10.1016/j.enconman.2014.05.083

Xiaomei, M., Ming, T., Huchang, L., Wenjing, S., \& Lev, B. (2019). The state-of-the-art survey on integrations and applications of the best worst method in decision making: why, what, what for and what's next? Omega, 87, 205-225. https://doi.org/10.1016/j.omega.2019.01.009

Yadav, G., Mangla, S. K., Luthra, S., \& Jakhar, S. (2018). Hybrid BWM-ELECTRE-based decision framework for effective offshore outsourcing adoption: a case study. Interna- 
tional Journal of Production Research, 56(18), 6259-6278. https://doi.org/10.1080/00207543.2018.1472406

Yadav, G., Mangla, S. K., Luthra, S., \& Rai, D. P. (2019). Developing a sustainable smart city framework for developing economies: an Indian context. Sustainable Cities and Societies, 47, 101462. https://doi.org/10.1016/j.scs.2019.101462

Yang, Y., Wong, K. K. F., \& Wang, T. (2012). How do hotels choose their location? Evidence from hotels in Beijing. International Journal of Hospitality Management, 31, 675-685. https://doi.org/10.1016/j.ijhm.2011.09.003

Yang, Y., Luo, H., \& Law, R. (2014). Theoretical, empirical, and operational models in hotel location research. International Journal of Hospitality Management, 36, 209-220. https://doi.org/10.1016/j.ijhm.2013.09.004

Yazdani, M., Zavadskas, E. K., Ignatius, J., \& Doval Abad, M. (2016). Sensitivity analysis in MADM methods: application of material selection. Inzinerine Ekonomika-Engineering Economics, 27(4), 382-391. https://doi.org/10.5755/j01.ee.27.4.14005
Yildiz, N., \& Tuysuz, F. (2018). A hybrid multi-criteria decision making approach for strategic retail location investment: application to Turkish food retailing. Socio-Economic Planning Sciences (in press). https://doi.org/10.1016/j.seps.2018.02.006

Zak, J., \& Weglinski, S. (2014). The selection of the logistics center location based on MCDM/A methodology. Transportation Research Procedia, 3, 555-564.

https://doi.org/10.1016/j.trpro.2014.10.034

Zavadskas, E. K., Turskis, Z., Antucheviciene, J., \& Zakarevicius, A. (2012). Optimization of weighted aggregated sum product assessment. Electronics and Electrical Engineering, 122(6), 3-6. https://doi.org/10.5755/j01.eee.122.6.1810

Zavadskas, E. K., Kalibatas, D., \& Kalibatiene, D. (2016). A multiattribute assessment using WASPAS for choosing an optimal indoor environment. Archives of Civil and Mechanical Engineering, 16(1), 76-85.

https://doi.org/10.1016/j.acme.2015.10.002 